\title{
Hubungan Antara Efikasi Diri Dan Regulasi Diri Dengan Prestasi Akademik Pada Mahasiswa Program Studi Ilmu Al-Qur'an Dan Tafsir UIN Raden Intan Lampung
}

\author{
Fitri Agustina \\ Program Studi Psikologi Islam \\ Universitas Islam Negeri Raden Intan Lampung \\ fitriagustina0711@gmail.com \\ M. Nursalim Malay \\ Program Studi Psikologi Islam \\ Universitas Islam Negeri Raden Intan Lampung \\ nursalimmalay@ radenintan.ac.id
}

\begin{abstract}
Academic achievement is an achievement achieved by someone in the academic field. This achievement can be achieved if a person has confidence and has the ability to manage him/her-self. This study aims to determine the relationship between self-efficacy and selfregulation with academic achievement in 57 students of the AlQur'an Science study program and the interpretation of UIN Raden Intan Lampung. The sampling technique used is sampling total then analyzed by multiple regression analysis techniques. The results of this research analysis explain that there is a relationship between self-efficacy and self-regulation with academic achievement in students of the study program of the Qur'an and the interpretation of UIN Raden Intan Lampung with a correlation coefficient $(R)=$ 0,859 and $F=76,136$ with $p=0,000$. Then, there is a significant relationship between self-efficacy and academic achievement in
\end{abstract}


students, the results of the analysis obtained are with the value of $r x_{1} y=0,817$ with $p=0,000$. Furthermore, there is a relationship between self-regulation and academic achievement in students seen from the results of calculations obtained by the value $r x_{2} y=0,854$ with $p=0,000$.

\begin{abstract}
Abstrak
Prestasi akademik adalah suatu pencapaian yang diraih seseorang dalam bidang akademis. Pencapaian tersebut dapat diraih apabila seseorang memiliki keyakinan serta memiliki kemampuan dalam mengatur dirinya sendiri. Penelitian ini bertujuan untuk mengetahui hubungan antara efikasi diri dan regulasi diri dengan prestasi akademik pada mahasiswa program studi Ilmu Al-Qur'an dan Tafsir UIN Raden Intan Lampung sebanyak 57 orang. Teknik sampling yang digunakan yaitu sampling total kemudian dianalisis dengan teknik analisis regresi berganda. Hasil analisis penelitian ini menerangkan bahwa ada hubungan antara efikasi diri dan regulasi diri dengan prestasi akademik pada mahasiswa program studi Ilmu Al-Qur'an dan Tafsir UIN Raden Intan Lampung dengan koefisien korelasi $(\mathrm{R})=0,859$ dan $\mathrm{F}=76,136$ dengam $\mathrm{p}=0,000$. Kemudian, ada hubungan yang signifikan antara efikasi diri dengan prestasi akademik pada mahasiswa, hasil analisis yang diperoleh yaitu dengan nilai $\mathrm{rx}_{1} \mathrm{y}=0,817$ dengan $\mathrm{p}=0,000$. Selanjutnya, ada hubungan antara regulasi diri dengan prestasi akademik pada mahasiswa yang dilihat dari hasil perhitungan yang diperoleh dengan nilai $\mathrm{rx}_{2} \mathrm{y}=0,854$ dengan $\mathrm{p}=0,000$.
\end{abstract}

Keywords: Academic Achievement, Self-Efficacy, Self-Regulation

\title{
Pendahuluan
}

Pendidikan diartikan sebagai ilmu pengetahuan ilmiah yang secara terus menerus mengalami perkembangan (Mulyadi, Basuki, \& Rahardjo, 2016). Setiap individu berlomba-lomba untuk menggapai pendidikan ke jenjang perguruan tinggi, baik melalui jalur reguler maupun jalur beasiswa. Di perguruan tinggi, salah satu pengembangan kualitas pendidikan sering dikaitkan dengan prestasi akademik mahasiswanya. Menurut El-Anzi (dalam Latipah, 2010) hal tersebut dikarenakan prestasi akademik merupakan satu diantara banyaknya acuan seseorang dalam dunia pendidikan. 
Tidak ada batasan bagi orang-orang yang ingin menuntut ilmu dan seseorang mampu meraih prestasi akademik yang tinggi apabila memiliki kemauan untuk mencapai keinginannya. Seperti Raeni, seorang anak dari pengayuh becak yang berpenghasilan tak menentu. Raeni merupakan salah satu mahasiswi penerima beasiswa bidik misi yang mengambil jurusan Pendidikan Akuntansi Fakultas Ekonomi di Universitas Negeri Semarang (Unnes) yang lulus sebagai wisudawati terbaik dengan Indeks Prestasi Komulatif (IPK) 3,96. Hal tersebut didapatkan dari usahanya selama kuliah dengan sangat mengatur waktu belajarnya bahkan ketika jeda pergantian jam mata kuliah (liputan6.com, 2014). Bahkan saat ini, Raeni sudah menyelesaikan pendidikan S2-nya di University of Birmingham, Inggris dan meraih gelar Master of Science (jateng.tribunnews.com, 2016).

Berdasarkan pemaparan di atas, prestasi akademik tidak bisa didapat secara langsung tanpa adanya usaha dari diri seseorang. Namun, Wahab (2015) \& Rachmahana (2008) menyebutkan bahwa prestasi akademik dapat diraih dengan adanya faktor-faktor yang mempengaruhinya diantaranya adalah efikasi diri dan regulasi diri. Efikasi dirimenurut Bandura (dalam Santrock, 2015) dianggap sebagai suatu keyakinan yang apabila individu mampu menguasai sesuatu yang menghasilkan hal yang positif dan nantinya akan mempengaruhi perilaku individu. Diduga, bila seorang individu memiliki efikasi diri yang tinggi, maka prestasi akademiknya pun akan tinggi.

Prestasi akademik, bukan hanya dicapai oleh individu yang memiliki keyakinan bahwa dirinya bisa melakukan hal tersebut dan yakin dengan kemampuan yang dimilikinya, hal tersebut dinamakan regulasi diri. Taylor, Peplau, \& Sears (2009), mengemukakan bahwa regulasi diri merujuk pada cara seseorang dalam mengontrol dan mengarahkan tindakannya. Regulasi diri adalah suatu upaya untuk mengendalikan pikiran, perasaan, dan perilaku dalam mencapai suatu tujuan (Boekaerts, Pintrich, \& Zeidner, 2000). Diduga, seseorang yang memiliki regulasi diri yang tinggi, maka prestasi akademiknya pun akan tinggi.

Semua mahasiswa memiliki kesempatan untuk membuktikan prestasi akademiknya, salah satunya adalah mahasiswa/mahasiswi Universitas Islam Negeri Raden Intan Lampung program studi Ilmu Al-Qur'an dan Tafsir. Program studi Ilmu Al-Qur'an dan Tafsir memiliki suatu tuntutan agar mahasiswa/mahasiswi yang berada di program studi tersebut untuk mampu mengkaji dan mempraktikkan kajian al-qur'an maupun hadits secara langsung melalui metode- 
metode yang telah mahasiswa tersebut ketahui dari berbagai tokohtokoh tafsir dan hadits baik yang sifatnya klasik maupun kontemporer. Oleh sebab itu, untuk mencapai pembelajaran yang maksimal, mahasiswa program studi Ilmu Al-Qur'an dan Tafsir harus memiliki keyakinan akan kemampuan yang dimiliki serta mahasiswa tersebut mampu mengelola dirinya sendiri dalam belajar sehingga mahasiswa tersebut mampu meraih prestasi akademik yang memuaskan.

Djamarah (2012) menyebut prestasi akademik sebagai prestasi belajar yang dapat dinyatakan sebagai penilaian yang dicapai dalam mata pelajaran atau mata kuliah tertentu, penilaian tersebut merupakan sebagai aktivitas dalam menentukan tinggi rendahnya prestasi akademik itu sendiri.

Prestasi akademik juga merupakan bentuk penguasaan pengetahuan atau keterampilan yang dikembangkan oleh mata pelajaran, biasanya ditunjukkan dengan nilai tes atau angka nilai (Wahab, 2015). Dalam pendidikan formal, prestasi akademik diaplikasikan dalam bentuk nilai atau kode tertentu yang melambangkan tingkat prestasi belajar, misalnya huruf A yang menunjukkan tingkat prestasi akademik yang sangat memuaskan, huruf $\mathrm{B}$ menunjukkan tingkat prestasi akademik yang memuaskan, huruf $\mathrm{C}$ menujukkan tinggat prestasi akademik yang cukup, huruf $\mathrm{D}$ menunjukkan tingkat prestasi akademik yang kurang memuaskan, dan huruf $\mathrm{E}$ menunjukkan tingkat prestasi akademik yang sangat rendah (Syah, 2015).

Istilah efikasi diri diperkenalkan oleh Albert Bandura. Bandura (dalam Ghufron \& Risnawita, 2012) mengungkapkan bahwa efikasi diri adalah keyakinan individu mengenai kemampuan dirinya dalam melakukan tugas atau tindakan dalam mencapai hasil yang diinginkan. Efikasi diri ini berhubungan dengan keyakinan bahwa diri memiliki kemampuan melakukan tindakan yang diharapkan. Efikasi diri cenderung konsisten sepanjang waktu, tetapi bukan berarti tidak berubah (Baron \& Bryne, 2004). Efikasi diri seseorang dapat mengatasi masalah dan hambatan apabila seseorang tersebut memiliki efikasi diri yang tinggi dalam mencapai tujuannya.

Baron, dkk (2004) berpendapat bahwa efikasi dirimerupakan penilaian individu terhadap kemampuan dan kompetensinya untuk melakukan suatu tugas, mencapai suatu tujuan dan menghasilkan sesuatu. Dengan kata lain, mahasiswa dengan efikasi diri positif merasa dapat mengontrol pembelajaran dan mereka percaya mempunyai kemampuan untuk berhasil. 
Menurut Fox \& Riconstence (2008) regulasi diri pada dasarnya adalah kegiatan yang diarahkan ke dalam diri untuk mengendalikan perhatian dan perilaku. Regulasi diriadalah salah satu aspek kepribadian manusia yang mampu mengontrol perilakunya sendiri. Apabila ingin mencapai tujuan yang diinginkan secara maksimal, maka seseorang harus mampu untuk mengontrol dan mengendalikan perilakunya sendiri.

Zimmerman (1998) menekankan bahwa bagi mahasiswa untuk mengembangkan pengaturan diri, tugas belajar harus mencakup peluang bagi mereka untuk mempraktikkan strategi ini sendiri. Regulasi dirimelibatkan proses kognitif, perilaku, dan metakognisi yang mencakup perencanaan, pengaturan dan pemantauan serta afeksi yang dimiliki dalam melaksanakan aktivitas-aktivitasnya.

\section{Metode Penelitian}

Penelitian ini merupakan penelitian yang menggunakan pendekatan kuantitatif dengan teknik analisis data berupa teknik analisis regresi berganda. Populasi dalam penelitian ini adalah mahasiswa program studi Ilmu Al-Qur'an dan Tafsir UIN Raden Intan Lampung tahun 2016 dan 2017 yang berjumlah 57 mahasiswa/mahasiswi. Teknik sampling yang digunakan dalam penelitian ini adalah sampling total, yaitudengan menggunakan semua anggota populasi yang berjumlah 57 mahasiswa/mahasiswi sebagai sampel dikarenakan jumlah populasi yang kurang dari 100 .

Penelitian ini menggunakan dua metode pengumpulan data. Pertama,dokumentasi yang berupa data mahasiswa program studi Ilmu Al-Qur'an dan Tafsir angkatan 2016 dan 2017 beserta Indeks Prestasi Komultatif (IPK) dari masing-masing mahasiswa tersebut selama mengikuti proses belajar mengajar. Data tersebut digunakan dalam proses pengambilan populasi dan sampel serta untuk mengungkap variabel terikat penelitian ini yaitu prestasi akademik yang dilihat melalui IPK dari masing-masing mahasiswa program studi Ilmu Al-Qur'an dan Tafsir angkatan 2016 dan 2017.

Kedua skala psikologi yang digunakan untuk mengukur dua variabel penelitian lainnya yaitu efikasi diri dan regulasi diri. Efikasi diri diukur dengan skala efikasi diri yang merupakan skala adaptasi dari Oktaviani (2018) yang akan diungkap berdasarkan aspek-aspek efikasi diri menurut Bandura (dalam Ghufron \& Risnawita, 2012) yaitu level, strength, dan generality. Jumlah aitem valid yaitu 37 dari 50 aitem. Regulasi diri diukur menggunakan skala regulasi diri yang 
dibuat oleh peneliti dan akan diungkap bedasarkan komponen regulasi diri dalam belajar oleh Zimmerman dan Schunk (2001) yakni, metakognisi, motivasi dan perilaku. Jumlah aitem valid yaitu 29 dari 40 aitem.

\section{Hasil dan Pembahasan}

Hasil dari data skala efikasi diri dan skala regulasi diri yang disebarkan pada subjek penelitian merupakan data skor yang sudah dianalisis dengan perhitungan statistik sebagaimana tertera dalam tabel berikut ini

Tabel 1. Deskripsi Data Penelitian

\begin{tabular}{|c|c|c|c|c|c|c|c|c|c|}
\hline \multirow[t]{3}{*}{ Variabel } & \multirow[t]{3}{*}{$\mathbf{N}$} & \multicolumn{4}{|c|}{ Skor Hipotetik } & \multicolumn{4}{|c|}{ Skor Empirik } \\
\hline & & \multirow[t]{2}{*}{ Mean } & \multicolumn{2}{|c|}{ Skor } & \multirow[t]{2}{*}{ SD } & \multirow[t]{2}{*}{ Mean } & \multicolumn{2}{|c|}{ Skor } & \multirow[t]{2}{*}{ SD } \\
\hline & & & Min & Max & & & Min & Max & \\
\hline $\begin{array}{c}\text { Efikasi } \\
\text { Diri }\end{array}$ & 37 & 92,5 & 37 & 148 & 18,5 & 113,23 & 90 & 146 & 10,635 \\
\hline $\begin{array}{c}\text { Regulasi } \\
\text { Diri }\end{array}$ & 29 & 72,5 & 29 & 116 & 14,5 & 89,44 & 74 & 113 & 8,139 \\
\hline
\end{tabular}

Metode analisis data berupa analisis regresi berganda. Perhitungan data dilakukan dengan bantuan program SPSS 22.0 for windows. Setelah dianalisis, adapun hasilnya adalah sebagai berikut.

1. Hasil analisis data memperoleh nilai koefisien korelasi $(\mathrm{R})=0,859$ dan $\mathrm{F}=76,136$ dengan $\mathrm{p}=0,000$ yang berarti bahwa ada hubungan antara efikasi diri dan regulasi diri dengan prestasi akademik pada mahasiswa program studi Ilmu Al-Qur'an dan Tafsir UIN Raden Intan Lampung.

2. Berdasarkan hasil analisis diperoleh $\mathrm{rx}_{1} \mathrm{y}=0,817$ dan $\mathrm{p}=$ 0,000 ( $\mathrm{p}<0,01$ ), yang berarti bahwa ada hubungan antara efikasi diri dengan prestasi akademik pada mahasiswa program studi Ilmu Al-Qur'an dan Tafsir UIN Raden Intan Lampung. Semakin tinggi efikasi diri seseorang, maka semakin tinggi prestasi akademik yang dicapai oleh seseorang.

3. Berdasarkan hasil analisis diperoleh $\mathrm{rx}_{2} \mathrm{y}=0,854$ dan $\mathrm{p}=0,000 \quad(\mathrm{p}<0,01)$, yang berarti bahwa ada hubungan 
antara regulasi diri dengan prestasi akademik pada mahasiswa program studi Ilmu Al-Qur'an dan Tafsir UIN Raden Intan Lampung. Semakin tinggi regulasi diri seseorang, maka semakin tinggi prestasi akademik yang dicapai oleh seseorang.

Berdasarkan penelitian yang telah dilakukan diketahui bahwa ada hubungan antara efikasi diri dan regulasi diri dengan prestasi akademik pada mahasiswa program studi Ilmu Al-Qur'an dan Tafsir UIN Raden Intan Lampung yang dapat ditunjukkan dengan hasil $\mathrm{R}=$ 0,859 dan $F=76,136$ dengan $p=0,000$. Hasil tersebut menunjukan bahwa semakin tinggi efikasi diri dan regulasi diri maka semakin tinggi prestasi akademik yang diraih mahasiswa/mahasiswi dan sebaliknya semakin tinggi rendah efikasi diri dan regulasi diri maka semakin rendah prestasi akademik yang diraih oleh mahasiswa/mahasiswi.

Djamarah (2012) menyebut prestasi akademik sebagai prestasi belajar dinyatakan sebagai penilaian yang dicapai dalam mata pelajaran atau mata kuliah tertentu, penilaian tersebut merupakan sebagai aktivitas dalam menentukan tinggi rendahnya prestasi akademik itu sendiri. Prestasi akademik dipengaruhi oleh beberapa faktor diantaranya adalah efikasi diri dan regulasi diri (Wahab, 2015) \& Rachmahana (2008)).

Baron, dkk (2004) berpendapat bahwa efikasi dirimerupakan penilaian individu terhadap kemampuan dan kompetensinya untuk melakukan suatu tugas, mencapai suatu tujuan dan menghasilkan sesuatu. Dengan kata lain, mahasiswa dengan efikasi diri positif merasa dapat mengontrol pembelajaran dan mereka percaya mempunyai kemampuan untuk berhasil. Penelitian yang telah dilakukan oleh Rachmahana (2008) yaitu "Peran Efikasi Diri terhadap Prestasi dan Performansi: Meta Analisis" menunjukkan bahwa ada hubungan yang sangat signifikan antara efikasi diri dan prestasi atau performansi individu dalam berbagai bidang melalui pengujian meta analisis.

Menurut Fox \& Riconstence (2008) regulasi diri pada dasarnya adalah kegiatan yang diarahkan ke dalam diri untuk mengendalikan perhatian dan perilaku. Regulasi diri melibatkan proses kognitif, perilaku, dan metakognisi yang mencakup perencanaan, pengaturan dan pemantauan serta afeksi yang dimiliki dalam melaksanakan aktivitas-aktivitasnya. Sebuah penelitian yang dilakukan oleh Rahayu, Yusmansyah, \& Utaminingsih (2017) menunjukkan bahwa terdapat 
hubungan yang signifikan antara regulasi diri dengan prestasi belajar siswa pada Kelas X SMA Negeri 1 Seputih Raman Lampung Tengah Tahun Ajaran 2016/2017.

Terwujudnya prestasi akademik yang diperoleh mahasiswa/mahasiswi secara maksimal, apabila mahasiswa mampu meyakini dirinya secara positif dan mampu mengontrol serta mengendalikan diri dengan baik. Maksudnya adalah ketika mahasiswa mampu meyakini dirinya sendiri bahwasannya mahasiswa tersebut mampu melakukan sesuatu dan mampu mengatur waktu yang dimiliki dengan baik, maka mahasiswa tersebut akan mampu mencapai tujuannya secara maksimal yaitu mendapatkan prestasi akademik yang tinggi.

Berdasarkan hasil analisis dari ketiga variabel, dapat diketahui jumlah sumbangan efektif masing-masing variabel bebas terhadap variabel terikat yaitu variabel efikasi diri memberikan sumbangan efektif sebesar $22,4 \%$ dan regulasi diri memberikan sumbangan efektif sebesar $51,4 \%$ yang berarti bahwa terdapat $73,8 \%$ kontribusi yang diberikan kedua variabel tersebut kepada variabel prestasi akademik. Selebihnya, ada 26,2\% dipengaruhi oleh faktor-faktor lain diluar penelitian ini seperti inteligensi, sikap belajar, bakat, minat belajar, motivasi belajar, penyesuaian diri, dan lingkungan.

\section{Simpulan dan Saran}

Berdasarkan penelitian yang telah dilakukan dapat disimpulkan bahwa; 1 . Ada hubungan antara efikasi diri dan regulasi diri dengan prestasi akademik pada mahasiswa program studi Ilmu Al-Qur'an dan Tafsir UIN Raden Intan Lampung, 2. Ada hubungan antara efikasi diri dengan prestasi akademik pada mahasiswa program studi Ilmu Al-Qur'an dan Tafsir UIN Raden Intan Lampung, 3. Ada hubungan antara regulasi diri dengan prestasi akademik pada mahasiswa program studi Ilmu Al-Qur'an dan Tafsir UIN Raden Intan Lampung.

Berdasarkan hasil penelitian yang telah dilaksanakan dan kesimpulan yang telah dipaparkan di atas, maka peneliti memberikan saran kepada pihak-pihak terkait untuk kemajuan bersama, saran tersebut ditujukkan untuk:

1. Subjek Penelitian

Bagi para mahasiswa/mahasiswi program studi Ilmu Al-Qur'an dan Tafsir UIN Raden Intan Lampung diharapkan agar lebih mampu melakukan pengelolaan di setiap tugas maupun tanggung jawabnya 
sebagai individu yang akademis, sehingga dapat meningkatkan prestasi akademiknya.

2. Dosen

Bagi tenaga pengajar atau dosen terkhusus dosen program studi Ilmu Al-Qur'an dan Tafsir UIN Raden Intan Lampung hendaknya dapat mengidentifikasi dan mengetahui masalah-masalah yang terjadi pada mahasiswa, misalnya dengan mengadakan pelatihan regulasi diri dan efikasi diri untuk para mahasiswa sehingga mahasiswa dapat meningkatkan serta mempertahankan prestasi akademik yang telah diraih.

3. Bagi Penelitian Selanjutnya

Bagi penelitian selanjutnya yang tertarik untuk meneliti dan mengkaji kembali efikasi diri dan regulasi diri dengan prestasi akademik diharapkan dapat lebih cermat dalam pengambilan subjek penelitian. Selain itu, bagi para peneliti selanjutnya diharapkan dapat menggunakan variabel lain yang dapat mempengaruhi prestasi akademik mahasiswa seperti inteligensi, sikap belajar, bakat, minat belajar, motivasi belajar, penyesuaian diri, dan lingkungan.

\section{Referensi}

Al-Qur'an dan Terjemahan : Special for Woman. (2013). Departemen Agama RI. Bandung : Syaamil Qur'an.

Alfiana, A.D. (2013). Regulasi Diri Mahasiswa Ditinjau dari Keikutsertaan dalam Organisasi Kemahasiswaan. Jurnal Vol. 01, No.02. Universitas Muhammadiyah Malang.

Arikunto, S. (2010). Prosedur Penelitian. Jakarta : Rineka Cipta.

Azwar, S. (2004). Prestasi Belajar. Yogyakarta : Pustaka Pelajar.

. (2015). Metode Penelitian. Yogyakarta : Pustaka Pelajar.

. (2016). Reliabilitas dan Validitas Edisi IV. Yogyakarta : Pustaka Pelajar.

Baron, R.A., \& Bryne, D. (2004). Psikologi Sosial Jilid 1.(Djuwita, R., Penerj.). Jakarta : Erlangga.

Bentley, J.C. (1966). Creativity and Academic Achievement. The Journal of Educational Research, Vol. 59, No. 6. (Diakses pada 23 Januari 2019, 16:47:36 di http://www.jstor.org/stable/2753171). 
Boekaerts, M., Pintrich, P.R., Zeidner, M. (2000). Handbook of Self Regulation. California : Academic Press. Diakses pada 30 Nopember 2018, 18:50:23

Crain, W. (2014). Teori Perkembangan (Konsep dan Aplikasi). (Santoso, Yudi, Penerj.). Yogyakarta: Pustaka Pelajar.

Djamarah, S. B. (2012). Prestasi Belajar dan Kompetensi Guru. Surabaya : Usaha Nasional.

Febriani, V. (2016). Pengaruh Efikasi diri dan Regulasi Diri terhadap Kemandirian Belajar Siswa pada Mata Pelajaran IPS. Jurnal Pendidikan Guru Sekolah Dasar Edisi 24 Tahun ke-5. Universitas Negeri Yogyakarta.

Fox, E., \&Riconstence, M. (2008). Metacognition and SelfRegulation in James, Piaget, and Vygotsky. Journal Educational Psychology Review, Vol. 20, No. 4. (Diakses pada 23 Januari 2019, 17:02:47 di http://www.jstor.org/stable/23363921).

Friedman, H.S., \& Schustack, M.W. (2008). Kepribadian (Teori Klasik dan Riset Modern). Jakarta : Erlangga.

Ghufron, M.N., \& Risnawita, R. (2012). Teori-Teori Psikologi. Yogyakarta : Ar-Ruzz Media.

https://iat.ushuluddin.radenintan.ac.id/ (Diakses pada 3 April 2019 pukul 22:17:23).

http://jateng.tribunnews.com/2016/11/21/tak-terasa-waktu-begitucepat-raeni-anak-tukang-becak-itu-sudah-lulus-s2-di-inggris. (Diakses pada 25 Februari 2019 pukul 14:48:50).

http://regional.kompas.com/read/2016/09/20/11263611/kisah.dewi .suryana.dari.keluarga.sederhana.lulus.memuaskan.di.singap ura.1.?page $=$ all. $($ Diakses pada 25 Februari 2019 pada pukul 14:56:10).

https://www.liputan6.com/news/read/2062384/kisah-raeni-si-anaktukang-becak-kejar-ilmu-hingga-inggris. (Diakses pada 25 Februari 2019 pukul 14:45:20).

Izzaty, R.E., Ayriza, Y., \& Setiawati, F.A. (2017). Prediktor Prestasi Belajar Siswa Kelas 1 Sekolah Dasar. Jurnal 
Psikologi Volume 44 Nomor 2. Universitas Negeri Yogyakarta.

Kirana, A. (2016). Faktor-Faktor yang Mempengaruhi Prestasi Akademik Mahasiswa. Tesis. Universitas Gadjah Mada.

Latipah, E. (2010). Strategi Self Regulated Learning dan Prestasi Belajar: Kajian Meta Analisis. Jurnal Psikologi Volume 37, No. 1. Universitas Islam Negeri Sunan Kalijaga.

Malay, M.N. (2019). Modul Praktikum Statistika (Analisis Data SPSS). Fakultas Ushuluddin dan Studi Agama UIN Raden Intan Lampung.

Malay, M.N., Fitriani, A., \& Islamia, I. (2019). Pedoman Penulisan Skripsi Prodi Psikologi Islam. Fakultas Ushuluddin dan Studi Agama UIN Raden Intan Lampung.

Minauli, I., \& Butarbutar, I. (2011). Hubungan antara Efikasi Diri dan Regulasi Diri dalam Belajar dengan Prestasi Akademik Mahasiswa. Jurnal Vol. 3 No.2. Universitas Medan Area.

Mulyadi, S., Basuki, H., \& Rahardjo, W. (2016). Psikologi Pendidikan : Dengan Pendekatan Teori- Teori Baru dalam Psikologi. Jakarta : Rajawali Pers.

Nugraheni, R.F. (2016). Kesabaran dan Academic Self-Efficacy pada Mahasiswa. Jurnal Psikologika Volume 21 Nomor 1. Universitas Indonesia.

Prasetyo, B., \& Jannah, L.M. (2011). Metode Penelitian Kuantitatif. Jakarta : Rajawali Pers.

Rachmah, D.N. (2015). Regulasi Diri dalam Belajar pada Mahasiswa yang Memiliki Peran Banyak. Jurnal Psikologi Volume 42, No. 1. Universitas Lambung Mangkurat, Banjarmasin.

Rachmahana, R.S. (2008). Peran Efikasi Diri terhadap Prestasi dan Performansi: Meta Analisis. Jurnal Psikologika Vol. 13 No. 2. Universitas Islam Indonesia.

Rahayu, R., Yusmansyah, Y., \& Utaminingsih, D. (2017). Hubungan antara Regulasi Diri dengan Prestasi Belajar Siswa. Jurnal Bimbingan Konseling Vol. 5 No. 5. Universitas Lampung. 
Rahman, A.A. (2013). Psikologi Sosial (Integrasi Pengetahuan Wahyu dan Pengetahuan Empirik). Jakarta : Rajawali Pers.

Rosito, A.C. (2018). Kepribadian dan Self-Regulated Learning. Jurnal Psikologi Volume 45 Nomor 3. Universitas HKBP Nommensen.

Santrock, J.W. (2015). Psikologi Pendidikan. (Wibowo, T., Penerj.). Jakarta : Prenadamedia Group.

Santrock, J.W. (2017). Adolescence (Perkembangan Remaja). (Adelar, S.B. \& Saragih, S., Penerj.). Jakarta : Erlangga.

Schultz, D.P., \& Schultz, S.E. (2016). Teori Kepribadian Edisi 10. (Diana, Paulina, Penerj.). Jakarta : Buku Kedokteran EGC.

Sugiyono. (2013). Metode Penelitian Kuantitatif, Kualitatif dan $R \& D$. Bandung : Alfabeta.

Sugiyono. (2015). Statistika untuk Penelitian. Bandung : Alfabeta.

Sugiyono. (2016). Metode Penelitian Pendidikan. Bandung : Alfabeta.

Syah, M. (2015). Psikologi Belajar. Jakarta : Rajawali Pers.

Taylor, S.E., Peplau, L.A., \& Sears, D.O. (2009). Psikologi Sosial. (Wibowo, T., Penerj.). Jakarta : Prenadamedia Group.

Wahab, R. (2015). Psikologi Belajar. Jakarta : Rajawali Pers.

Wahyuni. S. (2013). Hubungan Efikasi Diri dan Regulasi Emosi dengan Motivasi Berprestasi pada Siswa SMK Negeri 1 Samarinda. Jurnal Psikologi Vol. 1 Nomor 1. Universitas Mulawarman.

Winarsunu, T. (2015). Statistik dalam Penelitian Psikologi \& Pendidikan. Malang: UMM Press.

Zimmerman, B. J. (1998). Developing Self-Fulfilling Cycles of Academic Regulation: An analysis of Exemplary Instructional Models. In: Schunk, D. H., and Zimmerman, B. J. (eds.), Self-Regulated Learning: From Teaching to SelfReflective Practice, Guil- ford Press, New York.

Zimmerman, B.J., Schunk, D. H. (2001). Self-Regulated Learning and Academic Achievment. Mahwah, NJ : Erlbaum. 